\title{
URBAN RESETTLEMENTS AND ENVIRONMENTAL ENGINEERING AS A CONTEXT FOR HUMAN DEVELOPMENT. A CASE STUDY: HADE
}

\author{
Bujar Bajçinovci ${ }^{\text {a }}$, Florina Jerliu ${ }^{\text {a, } *}$ \\ ${ }^{a}$ University of Prishtina, Faculty of Civil Engineering and Architecture, Bregu i diellit p.n.10000 Prishtina, Kosovo \\ *Emails: florina.jerliu@uni-pr.edu; bujar.bajcinovci@uni-pr.edu
}

Received: 05.10.2016 / Accepted: 10.10.2016 / Revised: 26.11.2016 / Available online: 15.12.2016

DOI: 10.1515/jaes-2016-0011

KEY WORDS: environmental engineering, urban resettlements, surveying engineering, architecture, human development

\begin{abstract}
:
This paper explores the spatial considerations and relationship between necessity of expanding lignite mining, and urban resettlements as a context for human development and security. A situation is considered fragile when objective is to implement a strategy of safe resettlement. Moreover, those situations reflect how urban resettlement can be a social displeasure, despite health hazards of actual zones. The study presented in this paper explored the Shala neighbourhood of Hade village, focussing on urban resettlements, and environmental engineering issues. The research method consists of empirical observation throughout the zone, with an accent to the areas of resettlement. In order to receive a clear data and information, research is made within spatial regulation of urban planning, focusing on the environmental features regarding to the morphology of the area, air pollution, zones for expanding lignite mining and general hazards of public health. Case study was investigated through literature review, and the data collected includes maps, composition of urban structure, attributes of space, genius loci, and mining activities. Resettlements as a phenomenon pull away very sensitive social, safety and mental issues. We employ relatively new conceptual findings of urban planning, showing that the urban resettlement to a near village Shkabaj does not fulfil social, health and environmental objectives. Based on results of new resettlement area pollution, and urban planning issues presented in this paper, location for the resettlement of Shala neighbourhood of Hade village was not appropriate: as pattern for future urban resettlements in a context for environmental security and human development.
\end{abstract}

\section{INTRODUCTION}

This paper examines the spatial considerations and relationship between necessity of expanding lignite mining and urban resettlements as a context for human development, also study has examined the problems of the environment in relation to the actions of current power plants. Almost every power plant running on coil, with the old functional structure, more or less suffers from environmental degrade phenomenon, hence, how much they contribute to the degradation of the local communities and global environment it's a complex answer to address, moreover, it is a problem that directly affects the public health and whole ecosystem. Between man and his physical environment there is a dialectical bound: man, shapes the environment, and in return those action reforms him
(Churchill, 1944). Our desires to change the physical environment and avoiding to affect the man, leads to the unreasonable consequences, on the contrary, changing the space and environment firstly needs to be changed the man, mutual affecting the process of its own transformation and integration (Mandić, 2002).

"There is a growing body of evidence that, despite efforts by the international finance institutions and some national governments to set and apply standards in this area, people who are displaced by mining and other large scale developments typically have their rights diminished and are exposed to longterm disadvantage[...] resettlement is a complex, disruptive and dynamic process and that decisions and actions with good intent can still result in resettled peoples being worse off" (Lillywhite

\footnotetext{
* Corresponding author, e-mail: Florina Jerliu, florina.jerliu@uni-pr.edu
} 
at al, 2015). This study is based on the apparent lack of sustainability, security and poor quality housing in Shala neighbourhood. The overall objective of this research is to examine the possibility of integrating sustainability and resource efficiency to the environmentally healthy housing in a new resettlement. In order to test the efficacy of a new area for resettlement, the following parameters are indexed:

1. Adapting and implementation of urban plans

2. Research the zone: land, air, waste, wastewater

3. Ash and the impact on air pollution, environment of new area for resettlement

4. Power plants Kosovo A - B, impact on new locations

Kosovo is rich in minerals, especially on lignite. Lignite coal reserves are estimated to be sufficient for Kosovo, for the use of next few centuries. Rational and energy efficiency exploitation of this resource is very important for the development and ecology of the country. Hence, we need to have a special considerations on these activities, not only because that this production of energy is from fossils source, and from intensive and sometimes uncontrolled mining activities which creates major structural changes in the morphology of areas and environmental sustainability, but, it's inevitable for the next centuries that we will have lignite mining activities to fulfil the Kosovo electricity needs, thus, resulting with a potential hazards and direct impact on public health strategies.

"In the European Community (EC) the anticipated increased use of coal for power production will lead to an increase in the release of trace metals into the environment. This release seems unlikely to cause toxicological effects through the food chain, but there may be a possibility of a direct impact on man through inhalation. There are, however, many areas of uncertainty which need to be clarified by further research before a definitive assessment can be made" (Sabbioni et al., 19842003).

The study aims to evident that to fulfil successful integration of sustainability, energy efficiency and quality housing, there must be a balance of four interrelated basic elements:

1. Energy production, efficiency, and public health security.

2. Possible avoidance of major structural changes in environment.

3. Avoiding building residential areas in the vicinity of the coal ash dumps.

4. Preserving ecological environmental culture, history, and regional identity.

Additionally, exploitation of lignite reserves and other minerals in Kosovo threaten the increasing number of settlements in many zones, and particularly the Shala neighbourhood, because of the occupation of the land, and due to adverse and environmental other effects. Resettlement and displacement of the population is therefore a necessary consequence, in heavy mining activities and exploitation of the lignite as energy source. Hence, those mining actions result in fundamental processing conditions for the resettlements and aim in the most appropriate ways for displacement of inhabitants and households outside threatened zones. In this actual case, resettlement does not come from personal desires, motives or initiative of individuals, rather than imposed by external factors, moreover those activities are fundamentally in interest for Kosovar's general wellbeing. Globally and locally those systematic activities are complex environmental tasks, which involves many comprehensive objectives, bounded by relevant factors in the process of transformation, resettlement and displacement of a population. As a further action, there is urgency for holistic understanding of relationship and interdependence of those activities, in order to come with solution as an ecological proposal, aiming to the integrated and best possible environmental explication for a specific intervention on the researched area. Moreover, those wide morphological activities are quite complex tasks to implement.

"Access to electricity has a positive effect on the health and well-being of people worldwide. However, the use of coal to generate energy has negative health consequences. There is evidence of coal's impact on human health during every stage of its use for electricity generation from mining to post combustion disposal" (Burt et al., 2013).

"There are clear indications from the international health research literature that there are serious health and social harms associated with coal mining and coal-fired power stations for people living in surrounding communities" (Colagiuri et al., 2012).

"The pathology due to the atmosphere pollution holds an important place in the evaluation of the impact upon the health condition. It is unavoidable and absolutely normal to have the health of the population depend on the quality of the environment factors (air, water and ground), which indirectly or directly affect the human health. The air pollution is a major factor in triggering such disorders" (David et al., 2014). Hence: Does public health safety, exposure to pollutants, a vicinity of coal ash dump within new area chosen for resettlement of Shala neighbourhood, fulfil: social, urban, health and environmental objectives?

\section{MATERIALS AND METHODS}

\subsection{Urban Resettlement}

The study presented in this paper investigated the major new coalfield near Hade, focussing on urban planning issues, and air pollution. The research methods consist of empirical observation throughout the field, including collections of research materials and direct observation of the zone. In order to receive a clear data and information, research is made within spatial and environmental features, regarding to the morphology of the coal mining reservoir, urban planning, security, environmental pollution, and hazards of public health. Case study was investigated through literature review, documentations, graphic documentations, and drawings of the spatial morphological composition. The secondary data has collected: maps, 3D composition of urban structure, bioclimatic features and attributes of space, location of coal ash dumps. Furthermore, data has been collected from a selected village, which is a case study and was selected because, it was first 
government organized urban resettlement after war in Kosovo in 1999, and had some potential problems in its resettlement.

With the collected materials, the objective is to present a retrospective of actual state of the energy production industry, and the capacity of the energy resources of Kosovo, with the emphasis on the energy industry of Kosovo A-B, accompanied with the process of the resettlement for Shala neighbourhood of the Hade village. It should be clearly accented that the complexity of the situation cannot be holistically presented without a detailed, multidimensional and multidisciplinary approach; moreover, the main purpose of this paper is urban resettlement security. Human development dimensions are more than crucial after the heavy migrations to the main cities in the Kosovo, which was drastically manifested in the beginning of the new millennium, an entirely new urban challenge for the Kosovar communities.

\subsection{The Kosovo Energy Corporation}

The Kosovo Energy Corporation (KEC) is expanding lignite mining operations as the first phase of future development, expanding will result in the physical displacement of part of Hade village, the Shala neighbourhood. Hade village is located in central Kosovo in the Kastriot municipality, and is located near 10 kilometres of the Prishtina. Hade village is located directly on the contour of the existing Bardh and Mirash lignite mines. Expansion into the new mining areas is intended to ensure a secure supply of lignite over the next decades and centuries. The new mining areas will be exploited through surface mining, and development of the field is planned to begin to the southwest of Hade village and will extend to the Shala neighbourhood. Hence, there is 63 resident households and 320 residents (as of the 2011 survey), who will be physically displaced as result of those mining activities. The developed project also includes the properties and structured immoveable assets of closely 30 non-resident households who will also be economically displaced. In this context, all of the Shala neighbourhood homes structured temporary buildings and other properties in the Hade village will be dismantled along with all barns, outbuildings (MESP, 2011, 2013).

Sustainability development, among many definitions is quoted as, "development that meets the needs of the present without compromising the ability of future generations to meet their own needs" (WCED, 1987). The overall assessment is that the environmental degradation and pollution from mining activities in Kosovo is quite a serious problem. At all cost, we have to encourage the rehabilitation and for sure implementations of environmental heal strategies as presented in figure below (figure 1).

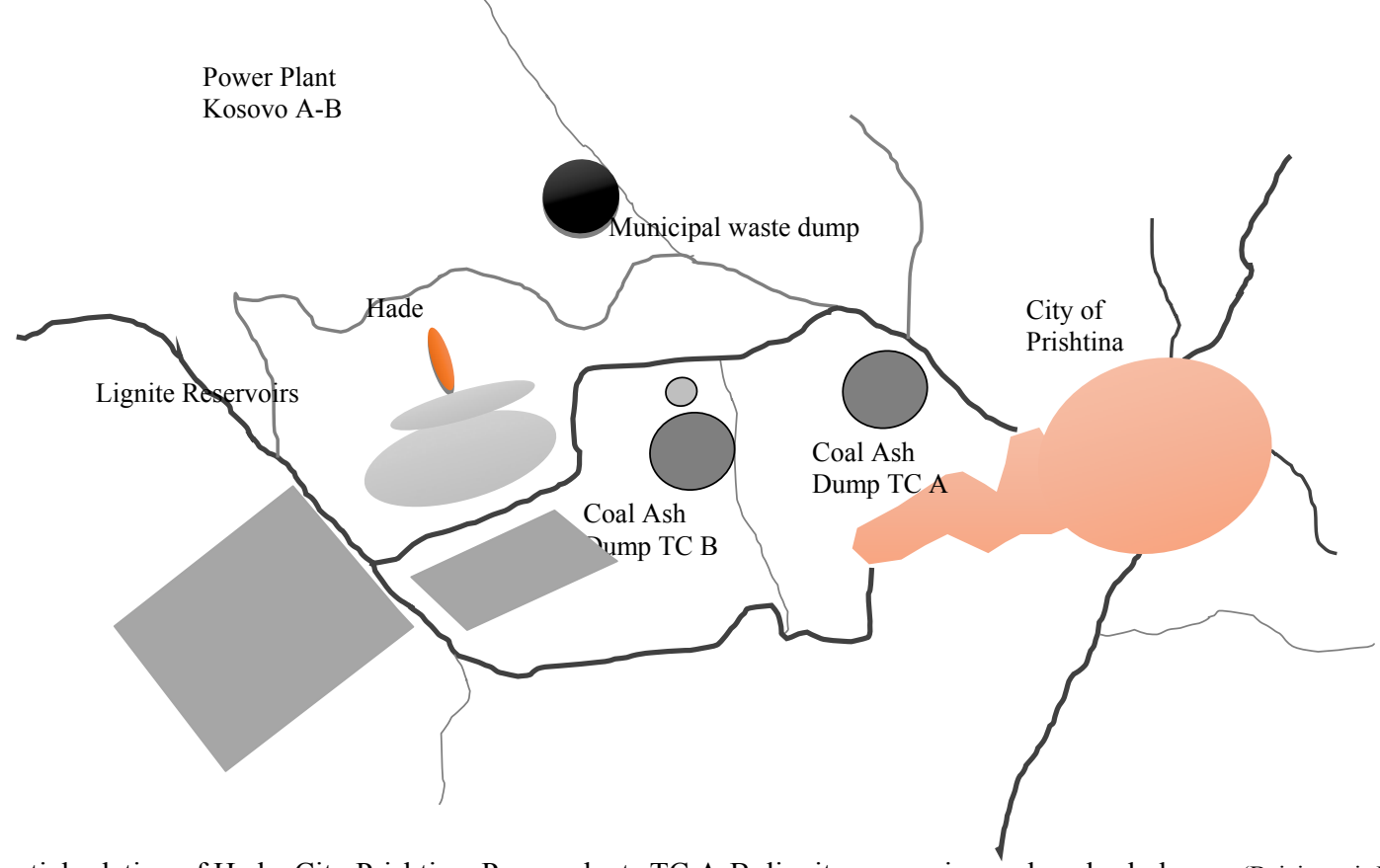

Figure 1. Spatial relation of Hade, City Prishtina, Power plants TC A-B, lignite reservoirs, and coal ash dumps (Bajçinovci, Jerliu, 2016)

"In late 2009, subsequent to Decision No. 08/66, the Government of Kosovo committed to undertake the land acquisition process in a manner that is compliant with international standards, namely the World Bank's Operational Policy on Involuntary Resettlement 4.12 and International Finance Corporation's (IFC) Performance Standards on Social and Environmental Sustainability.

In parallel, the Government initiated the preparation of a Resettlement Policy Framework (RPF) applicable to projects in the New Mining Field.The RPF was adopted by Government on 6 July 2011" (MESP, 2011, 2013). However, the Shala neighbourhood resettlement project is significant beyond its immediate purpose as it will establish exemplary standards and systems for resettlement as the coalfield is developed in the future (figure 2); thus, those overall activities present a pattern for future conceptual models for resettlement, aiming to be an example as the best prototype? 


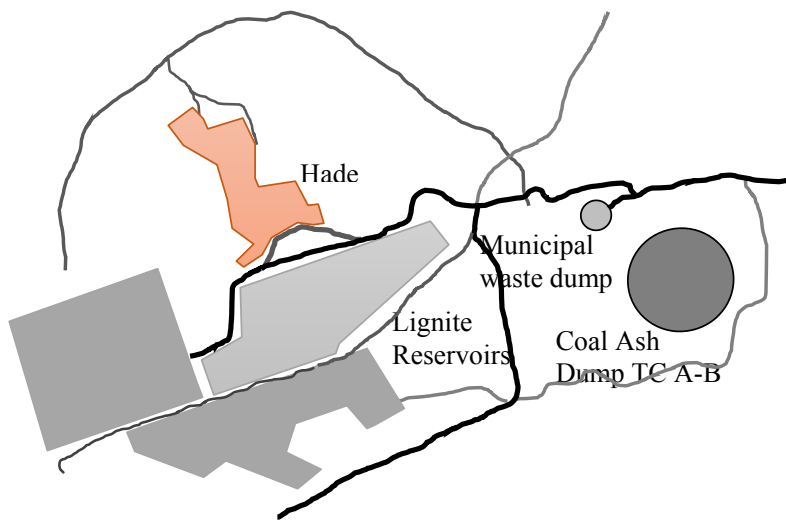

Figure 2. Spatial relation of Hade, lignite reservoirs, coal ash dumps and Prishtina waste dump (Bajçinovci, Jerliu, 2016)

As presented in figure 2, exposure to the concentrations of a number of chemicals and emissions into the air, drastically affects the housing and liveability near the mining areas and power plants TC A and B. Housing and health are eternal and universal issues, and more outstandingly near mining and heavy air pollution power plants. Emissions of $\mathrm{PM}_{\mathrm{xx}}$, the level of $\mathrm{CO}_{2}$ emitted, and other pollutants have a direct impact on public health, on the other hand, therein a great actions and attempt to cope valuable solution to the present and future environmental problems, thus, it is mandatory to present the data, conclusions and current surveys by World Health Organisation (WHO) and relevant EU directives. Three fundamental questions arrive within environmental conditions of researched area:

1. Systematisation, description and analysis of the existing conditions of liveability, the characteristics of economics and housing in new settlements, Shkabaj.

2. Exposure to concentrations to a greater number of chemicals and harmful emissions in the air, in new settlements, and energy production system of Kosovo power plants Kosovo A and B.

3. Socio-physiological aspects of resettlements as a context for human development.

\subsection{Global environmental actions}

Kosovo, in achieving of the environmentally health strategies, must also participate in global environmental actions, like, adoption measures of Kyoto Protocol, and lately of the Paris conclusions, hence, implementation is one of the key preconditions for a fitter and healthier living, because our communities and civil society very seriously hold standards regarding to the prevention of unlimited emissions of carbon dioxide and other gases that produce the effect of 'greenhouse gases' in the atmosphere and lead to the global warming. Moreover, the EU directives is much more severe than Kyoto Protocol findings, so the EU has set for its member's request that by 2010, emissions of harmful gas on its territory to be reduced by 8 percent compared to 1990 levels. Kyoto agreement signatories to the same task were given a deadline to 2012, and the maximum required reduction amounts was 5.2 percent, less than the request by EU. According to the present Climate Change Framework Strategy in Kosovo (MESP, 2014), it is also an opportunity to look for mitigation and adaptation of those measures, which will boost sustainable development and are very crucial for responding and anticipating of the impact of climate change in Kosovo. Those current activities and expected impacts include:

1. "Total emissions of all greenhouse gasses in 2008 in Kosovo reached $9.5 \mathrm{Mt} \mathrm{CO}_{2}$ eq. They increased by almost 11 percent to $10.5 \mathrm{Mt} \mathrm{CO}_{2}$ eq. in 2009. This relatively high increase was driven almost solely by increased fossil fuel combustion".

2. "In comparison with other countries in Europe Kosovo has relatively low emissions per capita (5.7 t $\mathrm{CO}_{2}$ equivalent per capita per annum in 2008 , while greenhouse gas emissions per unit of GDP $(0,84 \mathrm{~kg}$ $\mathrm{CO}_{2}$ equivalent per EUR in 2008) are higher. Per capita emissions are just over half of the EU average $(9.93 \mathrm{t})$ and emissions per unit of GDP are almost double of those in the EU average ( $0.4 \mathrm{~kg} / \mathrm{EUR})$ ".

3. "This situation justifies the application of the principle of common but differentiated responsibility defined in Article 3.1 of the United Nations Convention on Climate Change (UNFCCC)". (MESP, 2014).

4. "Energy sector produces about $82 \%$ of total national emissions of GHGs. This sector covers combustion, exploitation and distribution of fossil fuels in Kosovo. Combustion processes in energy industries in category $1 \mathrm{~A}$ make a decisive contribution to total emissions of GHGs, especially by carbon dioxide, which is produced when carbon-based fuels are burned". (MESP, 2014).

The Shala neighbourhood, forming the western part of Hade village, and the neighbourhood is 12.4 ha in size, in addition, other properties in Shala are owned by non-resident households who reside elsewhere in Kosovo. In total, the project of the MESP, affected the total of 510 people. Based on the survey, the 110 parcel owners in the Shala neighbourhood signed agreements by 2012 (MESP, 2011-2013).

At present, much of the Shala neighbourhood is considered to be at risk of subsidence, due to its proximity to the current mine edge, geological security with mining operations. Some residential properties and structures are situated less than 250 metres from the mine boundary edge, and mining framework activities.

Thus, the KEC in 2008 had included expropriation of 70 percent of the Shala neighbourhood, leaving intact the parts of the neighbourhood that do not fall within the zone of their first mine phase development. Through consultation with the Shala community leaders and members, it was determined that the Shala neighbourhood can be resettled as a whole (MESP, 20112013). According to the agreement the resettlement should only proceed once every individual agreement is finalized and compensation payments are made. The prospect of temporary 
displacement has been discussed with project affected community members for more than a year. Should temporary displacement occur, all resident households who have elected to move to replacement plots in the resettlement village will receive assistance with the identification of temporary accommodations and be entitled to a rental allowance. This assistance will be available to eligible households up to 4 months after access to replacement plots. Resident households who elected to receive cash compensation and acquire new accommodations elsewhere would be eligible for a rental allowance up to 4 months.

As of beginning of 2013, some of the families that were closest to the mine were moved to the temporary accommodation, and $\mathrm{KEC}$ is paying for their rent and other monthly allowances, the others who are within the security frame are still continuing to live in their homes and waiting for the new location to be finalized (MESP, 2011- 2013). In April 2004, the Shkabaj village site was selected by project affected households (MESP, 2013), and the current policy of compensation for impacted assets is presented in table 1 .

\begin{tabular}{|c|c|c|c|}
\hline $\begin{array}{l}\text { Impacted } \\
\text { Asset }\end{array}$ & $\begin{array}{l}\text { Entitled } \\
\text { Parties } \\
\end{array}$ & Eligibility & Compensation \\
\hline \multicolumn{4}{|l|}{ LAND } \\
\hline Rural land & $\begin{array}{l}\text { Recognized } \\
\text { owner or } \\
\text { Registered } \\
\text { owner with } \\
\text { full legal } \\
\text { title }\end{array}$ & $\begin{array}{l}\text { Recognize } \\
\mathrm{d} \text { or } \\
\text { registered } \\
\text { owner of } \\
\text { asset as of } \\
\text { entitlement } \\
\text { cut-off date }\end{array}$ & $\begin{array}{c}\text { Cash } \\
\text { compensation at } \\
\text { replacement } \\
\text { rates }\end{array}$ \\
\hline Urban land & $\begin{array}{l}\text { Recognized } \\
\text { owner or } \\
\text { registered } \\
\text { owner with } \\
\text { full legal } \\
\text { title }\end{array}$ & $\begin{array}{l}\text { Recognize } \\
\mathrm{d} \text { or } \\
\text { registered } \\
\text { owner of } \\
\text { asset as of } \\
\text { entitlement } \\
\text { cut-off date }\end{array}$ & $\begin{array}{c}\text { Standard } \\
\text { replacement plot } \\
\text { in new village } \\
\text { OR } \\
\text { Cash } \\
\text { compensation }\end{array}$ \\
\hline $\begin{array}{l}\text { Public } \\
\text { land }\end{array}$ & $\begin{array}{c}\text { Registered } \\
\text { owner } \\
\text { (municipal } \\
\text { government) }\end{array}$ & $\begin{array}{l}\text { Registered } \\
\text { owner of } \\
\text { asset as of } \\
\text { entitlement } \\
\text { cut-off date }\end{array}$ & $\begin{array}{c}\text { Replacement } \\
\text { with like lands } \\
\text { OR } \\
\text { Cash purchase }\end{array}$ \\
\hline \multicolumn{4}{|c|}{ STRUCTURES } \\
\hline $\begin{array}{l}\text { Residentia } \\
1 \text { structures }\end{array}$ & $\begin{array}{l}\text { Recognized } \\
\text { owner of } \\
\text { residential } \\
\text { structure on } \\
\text { construction } \\
\text { land }\end{array}$ & $\begin{array}{l}\text { Recognize } \\
d \text { owner of } \\
\text { asset as of } \\
\text { entitlement } \\
\text { cut-off date }\end{array}$ & $\begin{array}{c}\text { Standard } \\
\text { replacement } \\
\text { house in new } \\
\text { village. OR } \\
\text { Cash } \\
\text { compensation }\end{array}$ \\
\hline
\end{tabular}

Table 1. Current policy as applied by MESP and KEK in compensation negotiations with individual households (MESP, 2013)

The Shkabaj location was chosen, in part, due to the community preference for rural housing and the proximity to Prishtina, which is near $5 \mathrm{~km}$. The 44 ha Shkabaj village site will serve as the location for the resettlement of physically displaced households during several phases of mine expansions as was officially planned.

Hence, the new community will comprise nearly 1,000 urban plots, School and Kindergarten, Health Centre, Cemetery, and recreation areas, socially fulfilling the basic standards for liveability.

To ensure that replacement homes are adequate in size, materials and level of the finishing comply with municipal requests and standards, MESP has prepared a series of house design models. Project proponents must, according to the project, offer displaced persons and communities' compensation for loss of assets at full replacement cost, and other assistance to help them improve or at least restore their standards of living or livelihoods (MESP, 2013). Replacement value is defined as follows:

1. "The market value of rural land of equal productive use or potential located in the vicinity of the affected land, plus the cost of preparation to levels similar to or better than those of the affected land".

2. "The market value of land in urban areas of equal size and use, with similar or improved public infrastructure facilities and services preferably located in the vicinity of the affected land".

3. "The cost of household with be purchasing or building a new structure, with an area and quality similar to or better than those of the affected structure, or of repairing a partially affected structure" (MESP, 2014).

In the context of human development, we must accent the education structure of Hade village, respectively, most of the project affected adult population in Shala neighborhood has at least eight years of primary education, accurately 95 percent; including 93 percent of women. Fewer women continued on to complete secondary school, 59 percent, as compared with men of 89 percent. Also, 98 percent of the population defines themselves as literate (MESP, 2013) (table 2, table 3).

\begin{tabular}{|l|c|c|c|}
\hline Age & Male & \multicolumn{1}{|l|}{ Female } & Total \\
\hline $0-9$ & 50 & 41 & 91 \\
\hline $10-19$ & 50 & 48 & 98 \\
\hline $20-29$ & 46 & 68 & 114 \\
\hline $30-39$ & 41 & 36 & 77 \\
\hline $40-49$ & 29 & 27 & 56 \\
\hline
\end{tabular}

Table 2. Age Distribution in Project Affected Households (MESP, 2013)

\begin{tabular}{|l|l|l|}
\hline Source of Income & \# of Hhlds & $\%$ \\
\hline Permanent employment & 64 & $69 \%$ \\
\hline Remittances only & 10 & $11 \%$ \\
\hline Casual employment only & 6 & $6 \%$ \\
\hline Pensions only & 4 & $4 \%$ \\
\hline Other & 9 & $10 \%$ \\
\hline
\end{tabular}

Table 3. Sources of Income of Affected Households (MESP, 2013) 


\section{RESULTS AND DISCUSSION}

According to the World Operational Policy 4.12, (WOP) resettlement activities should be conceived and executed as sustainable development programs, providing sufficient investment resources to enable the persons displaced by the project to share in project benefits. Displaced persons should be meaningfully consulted and should have opportunities to participate in planning and implementing resettlement programs (MESP, 2013).

"The clinical and research literature shows a significant degree of psychological stress among refugees with relatively high levels of physical and psychological dysfunction during the first two years of resettlement; after three years, there was some improvement and increased adaptability, but there was still serious and pervasive adjustment problems" (Ater, 1998; Lipson, 1993; Chung, Kagawa-Singer, 1993).

"Our results suggested that internal displacement and resettlement might be related to higher internalization problems when some of the other confounding variables were controlled for. However, this effect was small. Further studies are needed to address the specific needs of internally displacement on affected individuals worldwide. This is especially important to identify rights and guarantees [...] the protection of displaced children and adolescents" (Erol et al., 2005). "The collective characteristics that had once united and strengthened the community's social structure began to dwindle. Meanwhile, a growing tendency towards individualistic characteristics gradually increased, causing the weakening and eventual dissolution of both the community and its social structure. The gradual process of community changes was reflected in the subjective narratives presented by community residents in a series of in-depth interviews conducted 4 years after the evacuation" (Billig, 2016). Spreading air pollution and health hazards to the near communities, in relation to the power plant emanations is presented in figure 3 .
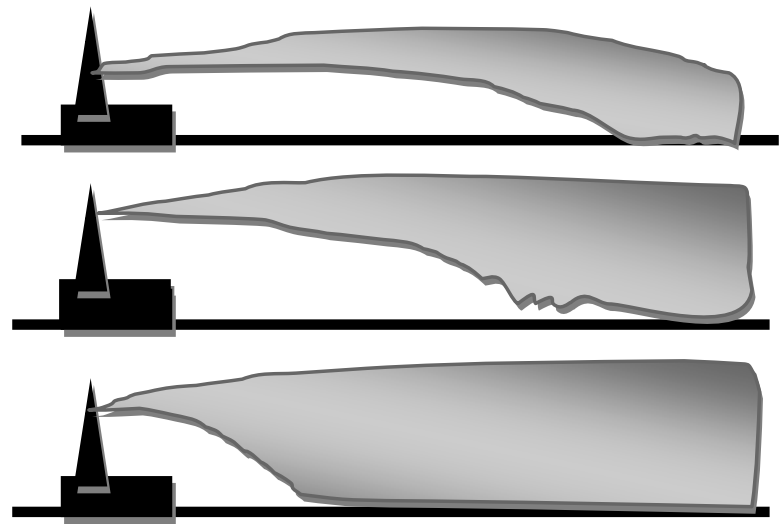

Figure 3. Spreading air pollution regarding to the velocity of wind: $1.0 ; 1.5 ; 4.0 \mathrm{~m}^{1} / \mathrm{sec}$, affecting more areas than those in vicinity of energy production (Bajçinovci, Jerliu, 2010)

Hence, more interestingly is that the households in Shipitullë, Grabovc, Dardhishte (Dardishte is also known as the "cancer village") and Hamidi, and their members have had the most health problems, unlike those in Hade, where they had the least health problems? Citizens of town Kastriot permanently declare that they or the other members of the family had some serious health problems over the past five years, with the most common respiratory diseases, heart and lung, cancer, mental problems and diabetes.

MESP had overseen the construction of replacement homes at the Shkabaj site, the majority of which will be constructed by the eligible households themselves. Nearly all eligible households have indicated their preference to undertake construction of their replacement houses themselves. Households undertaking their own construction of replacement homes will have to submit architectural plans to the municipality to receive building permits (MESP, 2013). To ensure that replacement housing is appropriate in size, materials and structure, MESP had prepared a series of house design patterns. As part of constructive negotiations, elective households will select preferred pattern of building model in advance of process, and applying for a building permit. The replacement of the homes to be built in the resettlement village will have advantages over the existing ones (MESP, 2013) (figure 4, figure 5).

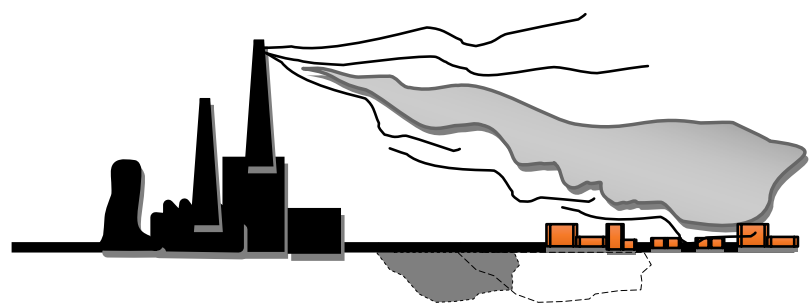

Figure 4. Spatial geological hazard and environmental pollution to the Hade village, according to the radius of emanation (Bajçinovci, Jerliu, 2016)

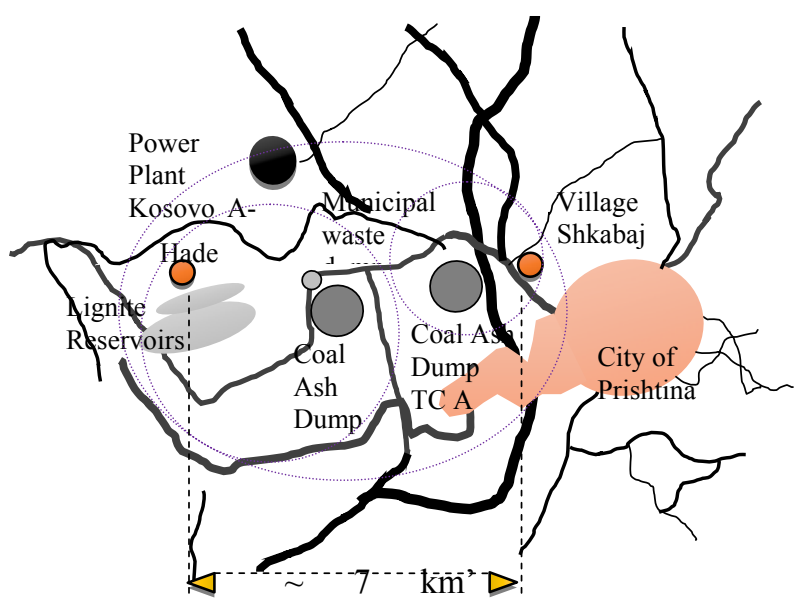

Figure 5. Spatial relation of Hade village, particularly, Shala neighbourhood, new chosen settlement, Shkabaj, and radiuses of potential air pollution (Bajçinovci, Jerliu, 2016)

In figure 5, we argue that there is no abundant difference from an old urban settlement with a new chosen one, regarding to the environmental pollution. According to the actual overall 
pollution, inhabitants of the new resettlement area Shkabaj are the same affected. Resettlements as a phenomenon pull away very sensitive social and mental issues. Displacement of populations affects directly in its way of life, history, security, indwelling, identification and the genius loci of the space, by which inhabitants are adapted to bring a symbiosis between community and nature (figure 6).

"Property is an inviolable and sacred right, no one shall be deprived thereof except where public necessity, legally determined, shall clearly demand it, and then only on condition that the owner shall have been previously and equitably indemnified" (Du Galland, 1789).

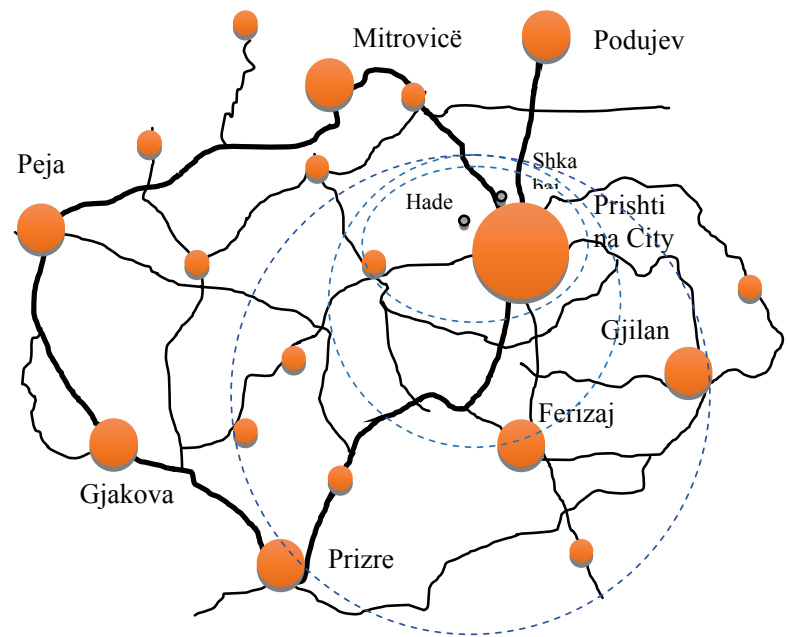

Figure 6. Kosovo spatial map, relation of Hade village and Shkabaj area. Preferred health radius rings 1, 2, 3 in Kosovo, for the new settlements of Hade Population (Bajçinovci, Jerliu, 2016)

\section{CONCLUSION}

Environmental pollution is a global issue, therefore, can't be addressed only locally, the current degraded state of environment and urban fabric requires specific responsibilities and activities, especially when the state is directly linked to the security, quality of life, public health, and sustainable architecture.

Thus, according to the results of this study, we prefer urban resettlements to be in much healthier environments, different than in this case study where new area for resettlement is within $7 \mathrm{~km}$ ' of the old affected area and the new mining activities, especially it is not the appropriate solution for a new settlement area which is near an existing coal ash dumps TC-A.

It is evident that the new area chosen for the resettlement, village Shkabaj has already health debase issues on pollution, and therefore, regarding to the overall pollution there is no difference with the new chosen urban neighbourhood in Shkabaj. Hence, as a sustainable urban strategy, a human development imperative can be a reconsideration to eventually change the new resettlement area.
Therefore, when vicinity to an existing coal ash dump is much more near to a new settlement this is an example of inadequate location for healthier living and human development. We employ a relatively new finding of urban resettlement, showing that the urban resettlement to a near village Shkabaj does not fulfil social, health and environmental objectives. Displacement of populations affects directly in its security, and human development. Based on results of a new resettlement area air pollution, and urban planning issues presented in this paper, location for the resettlement of Shala neighbourhood of Hade village was not appropriate: as a pattern for future urban resettlements in a context of health security, and human development.

Thus, we prefer that a new healthier area for resettlement is indubitably needed. The potential future work and research will be more focused on the environmental urban liveability of towns near power plants and coal mining activities.

\section{REFERENCES}

Ater, R. 1998. Mental Health Issues of Resettled Refugees: RN, University of Washington.

Billig, M. 2016. Effects of the forced resettlement of a community from an agricultural settlement to a high-rise building: GeoJournal, 81: 123. DOI: 10.1007/s10708-014-9604-4.

Burt, E, Orris, P, and Buchanan, S. 2013. Scientific Evidence of Health Effects from Coal Use in Energy Generation: University of Illinois, Chicago School of Public Health, USA.

Colagiuri R, Cochrane J, and Girgis, S. 2012. Health and Social Harms of Coal Mining In Local Communities: Spotlight on the Hunter Region. Beyond Zero Emissions, Melbourne.

Chung, R C, Kagawa-Singer, M. 1993. Predictors of Psychological distress among Southeast Asian refugees. Social Science and Medicine, 36(5), 631-639.

David, O, Valia, M, Maiduc, S. 2014. The impact of the mining activity on the economic sector, human health and environment: No. 2, Hidraulica. Magazine of Hydraulics, Pneumatics, Tribology, Ecology, Sensorics, Mechatronics. pp. 45-46.

Declaration des droits de l'homme et du citoyen / par A.F. Pison du Galland, membre de l'Assemble nationale, (1789). Prepared by Gerald Murphy, Distributed by the Cybercasting Services Division of the National Public Telecomputing Network (NPTN). Pp. 1-2.

Erol, N, Şimșek, Z, Öner, Ö and Munir, K. 2005. Effects of internal displacement and resettlement on the mental health of Turkish children and adolescents. European Psychiatry: The Journal of the Association of European Psychiatrists, 20(2), 152-157. http://doi.org/10.1016/j.eurpsy.2004.09.033.

Lipson, J. G. 1993. Afghan refugees in California: mental health issues. Issues in Mental Health Nursing, 14(4), pp. 411423. 
Lillywhite, S, Kemp, D. and Sturman, K. 2015. Mining, resettlement and lost livelihoods: Listening to the Voices of Resettled Communities in Mualadzi, Mozambique. Oxfam, Melbourne.

Mandić, R. 2002. Prostori Imaginacije. Spaces of Imagination. PhD Thesiss, Arhitektonski Fakultet, Sarajevo, BiH. pp.7-9.

MESP, 2011, 2013. Resettlement action plan, Shala Neighbourhood-Hade project Kosovo: Ministry of Environment and Spatial Planning. Kosovo Energy Corporation.

MESP, 2014. Climate Change Framework Strategy for Kosovo: Ministry of Environment and Spatial Planning. Kosovo.

Sabbioni, E, Goetz L., and Bignoli G., 1984. Health and environmental implications of trace metals released from coalfired power plants: an assessment study of the situation in the European Community. Published by Elsevier B.V., DOI: 10.1016/0048-9697(84)90348-6. 